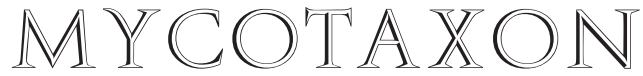

Volume 120, pp. 127-132

http://dx.doi.org/10.5248/120.127

April-June 2012

\title{
The fungal collection of the Jagiellonian University Herbarium (KRA), Kraków, Poland
}

\author{
Anna Maria Ociepa ${ }^{1}$, Szymon Zubek ${ }^{2} \&$ Piotr Mleczko ${ }^{2 *}$ \\ ${ }^{1}$ W. Szafer Institute of Botany, Polish Academy of Sciences \& \\ ${ }^{2}$ Institute of Botany, Jagiellonian University \\ ul. Lubicz 46, 31-512 Kraków, Poland \\ *CORRESPONDENCE To: ubmleczk@cyf-kr.edu.pl
}

Aвstract - The paper presents a short history of the mycological collection of the Jagiellonian University Herbarium (KRA, Kraków, Poland). The Herbarium holds over 22,000 specimens, including some interesting European and extra-European fungal exsiccata. One of the most valuable fungal collections (including many type specimens) in the Herbarium is that containing Javanese fungi gathered by Marian Raciborski at the end of $19^{\text {th }}$ century.

Key words - fungi of Pieniny Mts., fungi of Gorce Mts., ascomycetes, basidiomycetes, Peronospora

\section{The history}

The origin of the Jagiellonian University Herbarium dates back to 1780, when the Faculty of Chemistry and Natural History was established, and with it the Natural History Room (Köhler 1999; Köhler 2001a). The Herbarium, which was long associated with the Chair of Botany at the Botanical Garden, is now part of the Institute of Botany of Jagiellonian University.

The first record of fungi being kept in the Herbarium dates from 1812, and the oldest specimen with a date placed on the label is from 1807 (FIG. 1). In the past the Herbarium collections served mainly an educational function (Köhler 2001b). Until 1910 each set of specimens, including purchased, exchanged, or donated exsiccata and collections, was kept separately and a taxonomic criterion was not applied to the Herbarium's arrangement. Between 1910 and 1918 the collections were merged, and all specimens were arranged taxonomically (Köhler 2001a).

After the Second World War the fungal collection was separated from plant collections and arranged by Barbara Gumińska, who in 1950 became the first curator of the Herbarium's mycological section (Köhler 2001b) and served 


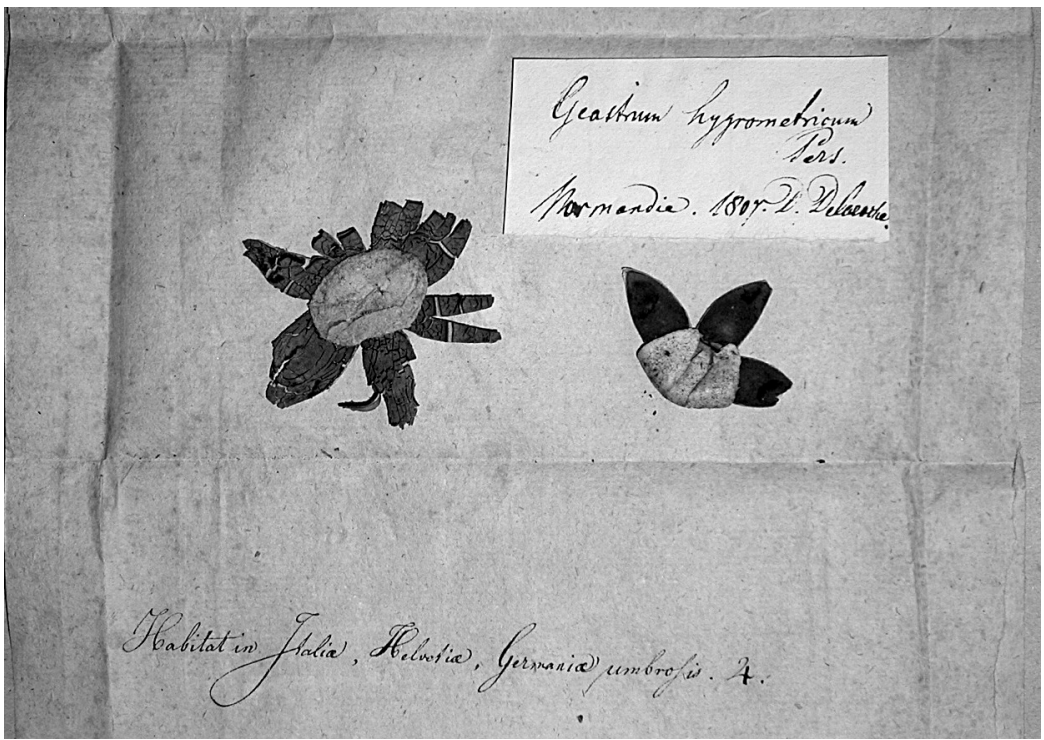

Plate 1. The oldest specimen in the fungal collection of the Jagiellonian University Herbarium: “Geastrum hygrometricum Pers. Normandie. 1807. D. Delaroche (?). Habitat in Italia, Helvetia, Germania umbrosis. 4."

as curator until her retirement in 1993. The next curator, Katarzyna Turnau (1993-2005), was succeeded by Piotr Mleczko, who currently holds this post.

Until 2006 the specimens in the mycological collection were not numbered. In that year all specimens were counted and most of them were assigned numbers. The collection now contains 20,195 numbered specimens: 5564 Ascomycota, 11,098 Basidiomycota, 2682 anamorphic fungi, and 851 fungus-like organisms (mostly Peronospora in the Oomycota). In addition it holds also about 900 unnumbered macromycete specimens collected by Barbara Gumińska in Pieniny National Park, Poland.

\section{The collections}

One of the most valuable fungal collections is the Javanese collection of Marian Raciborski. Raciborski's collection dates back to 1896-1900 and consists of dried specimens marked with 'J' (Java) after the number (FIG. 2) as well as some samples preserved in ethanol-formaldehyde solution, which are in the Botanical Garden Museum (Köhler \& Zemanek 1989). According to Wojewoda (1986), Raciborski described 235 new fungal taxa from Java, all tropical microfungi except for one macromycete. Many genera and species described by Raciborski are still accepted under his names: e.g. Aldona 


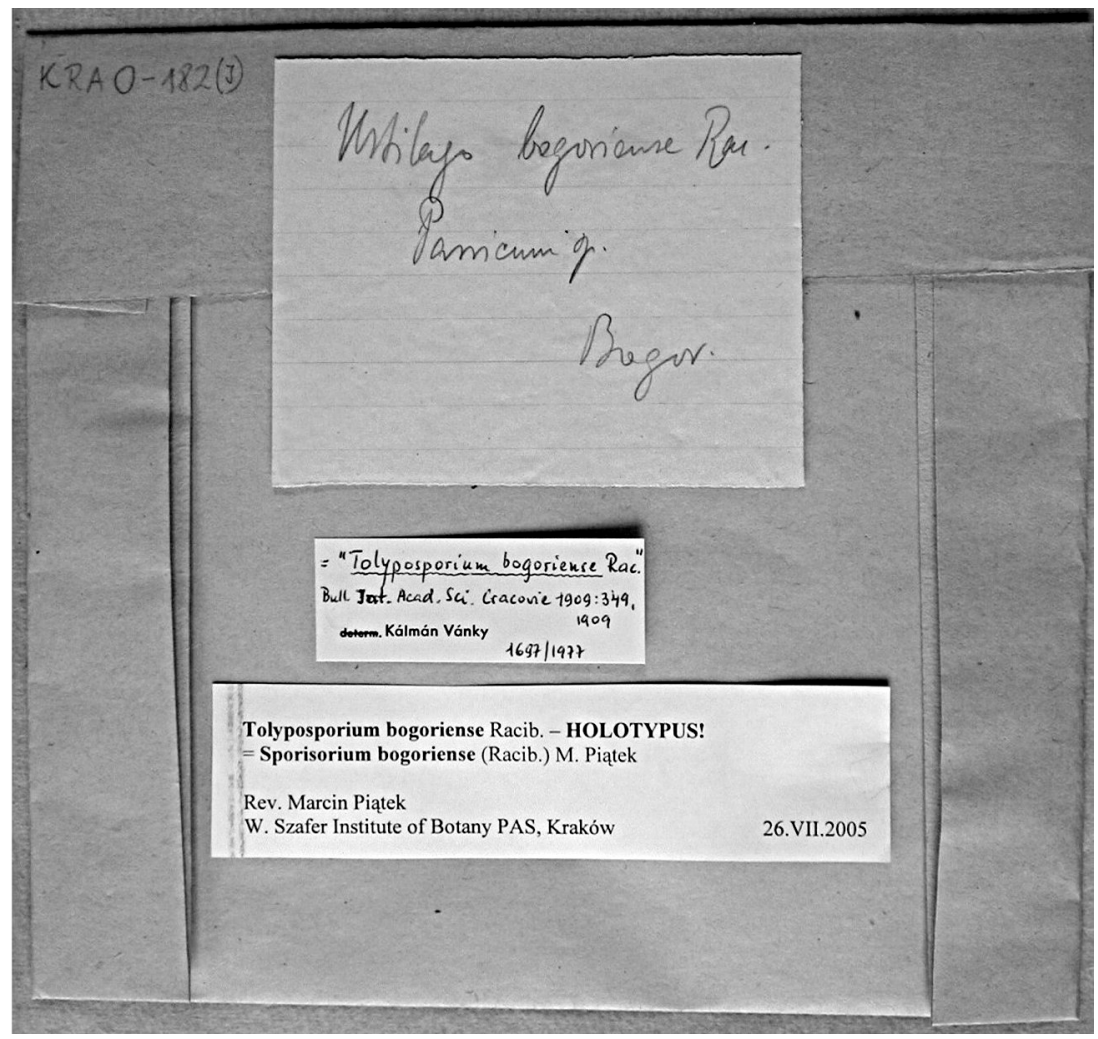

Plate 2. A specimen from the Javanese collection of Marian Raciborski: "Ustilago bogoriense Rac., Panicum sp., Bogor."

(A.stella-nigra), Alina (A.jasmini), Anhellia (A.tristis), Balladyna (B.gardeniae), Farysia (F. javanica), Goplana (G. aporosae, G. micheliae, G. mirabilis), Lambro (L. insignis), Ordonia (O. orthobasidion), Skierka (S. agallocha, S. canarii), and Telimena (T. erythrinae) (Index Fungorum 2011).

Other important exsiccata kept in KRA are those of Karl Wilhelm Gottlieb Leopold Fuckel, Otto Jaap, Gottlob Ludwig Rabenhorst, Heinrich Rehm, Pier Andrea Saccardo, Trajan Săvulescu, Hans Sydow, and Charles Wright (see the list below), which comprise many syntypes. At present only the exsiccati of Ascomycota are catalogued, comprising 134 syntypes.

The fungal section also holds many specimens gathered in Poland, including three holotypes: Exobasidium dubium Racib., Wawelia regia Namysl. (an exotic species found in the Botanical Garden of the Jagiellonian University, Kraków), and Geopyxis rehmii Turnau. The most important Polish collections were 
contributed by Władysław Wojewoda (1932-2010) from Ojców National Park (macromycetes), Katarzyna Turnau from the Gorce Mts. (larger ascomycetes), and Barbara Gumińska from Pieniny National Park. Recently Piotr Mleczko and co-workers made a significant collection of fungi, mostly from southern Poland, which is now being incorporated into the Herbarium and will increase the number of specimens by approximately 1000 .

The most important fungal exsiccata and collections in the Herbarium mycological section are listed below. It should be noted that the Taxonomic Literature series (Stafleu \& Cowan 1976-88; Stafleu \& Mennega 1992-2000) and the monographs by Stevenson (1971) and Pfister (1985) mostly do not mention the sets stored at Jagiellonian University Herbarium.

The names of fungal collections, dates, and authors follow (where possible) Stafleu \& Cowan (1976-88), Stafleu \& Mennega (1992-2000), Pfister (1985), or Stevenson (1971). Otherwise data are based on exsiccata labels or, with respect to author life spans, from various sources cited with each collection).

\section{Abbreviations}

IF - Index Fungorum (www.indexfungorum.org)

SC-1-7 - Stafleu \& Cowan (1976-88), vols. 1-7

Pf - Pfister (1985)

St - Stevenson (1971)

\section{Polish COLLECTIONS}

- Fungi bialowiezenses exsiccati, Wincenty Siemaszko (1887-1943) [Köhler 2002, Pf, SC-5].

- Fungi parasitici Poloniae exsiccati, Marian Raciborski (1863-1917) [PiekiełkoZemanek 1986, Wojewoda 1986].

- Mycotheca polonica, Marian Raciborski and Bolesław Namysłowski (1882-1929) [Köhler 2002, Wojewoda 1986].

- Mycotheca polonica, Józef Kochman (1903-95) and Bogusław Sałata (1940-99) [Majewski 1995, Chmiel \& Mułenko 1999, Pf].

\section{European COLLECTIONS (EXCEPt Poland)}

- Ascomyceten, Ascomycetes exsiccatae, Heinrich Rehm (1828-1916) [St; Pf; SC-6].

- Cryptogamae Cechoslovenicae exiccatae, František Šmarda (1904-68) [SC-5].

- Flora Hungarica, Gabriel Bohus (1914-2005) [IF].

- Flora hungarica exsiccata. Sectio botanica Musei Nationalis Hungarici, Budapest.

- Flora Lituana Exsiccata Fungi parasitici, Antanas Minkevičius (1900-98) [Botanikos ir genetikos katedra 2011; Pf].

- Flora Romaniae exsiccata, Alexandru Borza (1887-1971) [Pop 1972; Pf; SC-1].

- Fungi bavarici exsiccati, Andreas Allescher (1828-1903) and Johann Nepomuk Schnabl (1853-99) [Pf; SC-1,5].

- Fungi bohemici, František Bubák (1865-1925) [SC-1]. 
- Fungi Europaei exsiccati Klotzschii herbarii vivi mycologici continuatio. Editio nova. Series secunda, Gottlob Ludwig Rabenhorst (1806-81) [Pf; St; SC-4].

- Fungi rhenani exsiccati, Karl Wilhelm Gottlieb Leopold Fuckel (1821-76) [SC-1].

- Fungi Schemnitziensis, Andreas Kmet (1841-1908) [Lizoň 1973; Pf].

- Fungi selecti exsiccati, Otto Jaap (1864-1922), Carl Brick (1863-1924) [Pf; SC-2].

- Griby Rossii, Gavril Stepanowich Nevodovskij (1874-1952) and Voldemar Tranzschel (1868-1942) [Karczmarz \& Sałata 1982; Pf; SC-6].

- Herbarium mycologicum romanicum, Trajan Săvulescu (1889-1963) [Pf; SC-5].

- Klotzschii herbarium vivum mycologicum, Gottlob Ludwig Rabenhorst [Pf; St; SC-4].

- Klotzschii herbarium vivum mycologicum, editio novo, Gottlob Ludwig Rabenhorst [Pf; St; SC-4].

- Kryptogamae exsiccatae editae a Museo Palatino Vindobonensi, Günter von Beck (1856-1931), Alexander Zahlbruckner (1860-1938), Karl von Keissler (18721965), Franz Petrak (1886-1973) [Pf; St; SC-1,2,7].

- Mycotheca germanica, Paul Sydow (1851-1925), Hans Sydow (1879-1946) [Pf; SC-6].

- Mycotheca veneta, Pier Andrea Saccardo (1845-1920) [Pf; SC-4].

- Plantae cryptogamicae, quas in Arduenna collegit (Plantae cryptogamicae Arduennae), Marie-Anne Libert (1782-1865) [Pf; SC-3].

\section{EXTRA-EUROPEAN COLLECTIONS}

- Cryptogamae parasiticae in Insula Javae lectae exsiccatae, Marian Raciborski [Pf]

- Fungi cubenses wrightiani, Charles Wright (1811-86) [St; SC-7].

- Fungi exotici exsiccati, Hans Sydow [St; Pf; SC-6].

- Ohio Fungi, William Ashbrook Kellerman (1850-1908) [St; Pf; SC-2].

Loan requests should be directed to: Institute of Botany Herbarium (Fungal collection), Jagiellonian University, Kopernika 31, 31-501 Kraków, Poland. Curator of the mycological collection: Dr. Piotr Mleczko.

The Herbarium web-page is http://www.ib.uj.edu.pl/en/?d=zielnik

\section{Acknowledgments}

Anna Maria Ociepa would like to thank Professor Adam Zając for employment in Herbarium of Jagiellonian University in 2006. The authors wish to thank Professor Reinhard Agerer and Professor Reinhard Berndt for their very valuable comments on the manuscript.

\section{Literature cited}

Botanikos ir genetikos katedra. 2011. Profesorius Antanas Minkevičius [http://www.bg.gf. vu.lt/?Personalas:Anks\%C4\%8Diau_dirb\%C4\%99_i\%26scaron\%3Bkiliausi_katedros \%C5\%BEmon\%C4\%97s:Profesorius_Antanas_Minkevi\%C4\%8Dius (viewed online on 4 November 2011)]. (in Lithuanian)

Chmiel MA, Mułenko W. 1999. Professor Bogusław Sałata (1940-1999). Acta Mycologica 34(1): 3-5. 
Index Fungorum 2011. [http://www.indexfungorum.org/Names/Names.asp (viewed online 4 November 2011)].

Karczmarz K, Sałata B. 1982. Studies and botanical achievements of G.S. Nevodowski (1874-1952). Annales Universitatis Mariae Curie-Skłodowska, Sectio C, Biologia 37: 223-231. (in Russian, with English summary)

Köhler P. 1999. History of the Jagiellonian University Herbarium (KRA) (Cracow, Poland) in 1780-1910. Kwartalnik Historii Nauki i Techniki 44(2): 7-60. (in Polish with English summary)

Köhler P. 2001a. History of the Jagiellonian University Herbarium (KRA) (Cracow, Poland) in 1910-2000. Kwartalnik Historii Nauki i Techniki 46(4): 77-104. (in Polish with English summary)

Köhler P. 2001b. History of the Jagiellonian University Herbarium (KRA), Cracow, Poland. Taxon 50: 943-945.

Köhler P. 2002. Botany at the Academic Society of Cracow, Academy of Sciences and Letters and the Polish Academy of Sciences and Letters (1815-1952). Studia i materiały do dziejów Polskiej Akademii Umiejętności. Tom II. Polska Akademia Umiejętności, Kraków. (in Polish with English summary)

Köhler PS, Zemanek A. 1989. The Marian Raciborski collection in the Museum of the Jagiellonian University Botanical Garden. Zeszyty Naukowe UJ 926, Prace Botaniczne 18: 135-148. (in Polish with English summary)

Lizoň P. 1973. Andrej Kmet’ a mykologický výskum Slovenska. Česka Mykologie 27(3): 177-179.

Majewski T. 1995. Józef Kochman (1903-1995). Rocznik Towarzystwa Naukowego Warszawskiego 58: 55-57. (in Polish)

Pfister DH. 1985. A bibliographic account of exsiccatae containing fungi. Mycotaxon 23: 1-139.

Piekiełko-Zemanek A. 1986. A calendar of life of Marian Raciborski. 9-43, in: J Kornaś (ed.): Marian Raciborski. Studia nad życiem i działalnością naukową. Zeszyty Naukowe UJ, Varia 210. (in Polish with English summary)

Pop E. 1972. In memoriam Elexandre Borza (1887-1971). Vegetatio 25(5-6): 273-277. (in French) http://dx.doi.org/10.1007/BF02198407

Stafleu FA, Cowan RS. 1976-88. Taxonomic literature. Volume I-VII. Regnum Vegetabile 94-116.

Stafleu FA, Mennega EA. 1992-2000. Taxonomic literature. Supplement I-VI, Regnum Vegetabile 125-137.

Stevenson JA. 1971. An account of fungus exsiccati containing material from the Americas. Beihefte zur Nova Hedwigia 36: 1-563.

Wojewoda W. 1986. Mycology in the scientific output of Marian Raciborski. 59-78, in: J Kornaś (ed.): Marian Raciborski. Studia nad życiem i działalnością naukową. Zeszyty Naukowe UJ, Varia 210. (in Polish with English summary) 